\title{
ОРГАНІЗАЦІЙНІ ЗАХОДИ ІЗ ЗАБЕЗПЕЧЕННЯ ПРОТИДІЇ ПРАВОПОРУШЕННЯМ У СФЕРІ ГОСПОДАРСЬКОЇ ДІЯЛЬНОСТІ В УКРАЇНІ
}

\author{
СУГАК Олексій Вікторович - здобувач Університету сучасних знань \\ УДК: 342.95 (477) \\ https://orcid.org/0000-0003-4253-6439 \\ DOI 10.32782/EP.2020.3.10
}

\begin{abstract}
У статті проаналізовано сутність та поняття організачійних заходів із забезпечення протидї правопорушення у сбері господарської діяльності в Украӥні. На прикладі законодавчих положень побудовано теоретичну позииію щодо структурно-управлінсъких, внутрішнъокоординаційних та інбормачійно-аналітичних заходів забезпечення протидї правопорушенням у господарському секторі держави.

Доведено, що поняття «організачія» містить у собі глибоке змістовне навантаження, внаслідок чого може тлумачитись двояко.3 одного боку, організація - це особлива сукупність певних об'єктів, що характеризується жорсткою внутрішнъою упорядкованістю, найвишим ступенем внутрішнъої дисципліни елементів, які не просто співіснують між собою, але й взаємодіють. Відповідно до іншого тлумачення, організачія - це упорядковуюча діяльність, метою якоӥ є приведення певной системи об'єктів до відповідного стандартизованого, заздалегідв визначеного вигляду. Таким чином, говорячи про організаційні заходи iз забезпечення протидї правопорушенням у сфері господарської діяльності ми маємо на увазі сукупність дій управлінсъкого характеру, які направлено на упорядкування внутрішньої структури, внутрішнъо-владних процесів, які виникають у поточній діяльності суб'єктів адміністративно-правової протидіи досліджуваному в статті явищу.

Встановлено, щзо організачійні заходи займають важливе місие у фбункиіоналі суб'єктів протидї правопорушенням в сфері
\end{abstract}

господарсъкої діяльності. Про їх значимість та важливість досить яскраво каже той факт, шьо в своїй багатоманітності дані заходи об’єднуються вгрупи, асаме: заходи структурноуправлінсъкі, внутрішнъо-координащійні та інбормачійно-аналітичні. Таким иином, організаційні заходи є необхідними аспектами підтримки ебективності діяльності, а також удосконалення роботи органів влади, що в кінцевому результаті має позитивний вплив на рівень дієвості реалізованої ними протидії правопорушенням у сбері господарсъкої діяльності.

Ключові слова: правопорушення, господарсъка діяльність, організачійні заходи, забезпечення протидї.

Постановка проблеми

Державний апарат є складним механізмом, що знаходиться в постійному pусі, а його елементи невпинно взаємодіють одне 3 одним. Однак, як і будь-який механізм апарат держави має певні недоліки, а його елементи можуть втрачати свою функціональну орієнтованість. У цій площині важливою є організаційна спроможність нашої країни до саморегуляції. Так, за допомогою набору різних організаційних заходів держава може самостійно забезпечувати належну роботу своїх владних органів та відомств. При цьому, організаційно-забезпечувальна складова наявна в усіх без винятку спектрах роботи України, як суб'єкта правовідносин, 
зокрема, у контексті протидії правопорушенням у сфері господарської діяльності.

\section{Стан дослідження проблеми}

У рамках дослідження проблеми організаційних заходів, ціллю яких є забезпечення протидії правопорушенням у сфері господарської діяльності в Україні, було охарактеризовано праці вчених, які аналізували проблематику організації державної влади, побудови їі внутрішніх процесів для досягнення найбільш ефективного результату. Так, використано досвід таких учених, як П.М. Каркач, О.Б. Червякова, I.Є. Марочкін, Б.Г. Савченко, К.I. Мельников, А. Т. Комзюк, А.М. Куліш, О.М. Музичук, Ю.В. Боковиков, С.І. Білосорочка та інші.

\section{Мета і завдання дослідження}

Мета і завдання наукової статті полягають у формуванні поняття організаційних заходів із забезпечення протидії правопорушенням у сфері господарської діяльності, а також виділенні їх безпосередніх різновидів.

Наукова новизна дослідження полягає в тому, що стаття є першою працею в межах якої проведено комплексний аналіз організаційних заходів із забезпечення протидії правопорушенням у сфері господарської діяльності, а також запропоновано їх класифікацію.

\section{Виклад основного матеріалу}

Для розуміння змісту та виділення прикладів організаційних заходів із забезпечення протидії правопорушенням у сфері господарської діяльності звернемо увагу на етимологічну основу цієї категорії, а саме слово «організація». Цей термін має декілька іншомовних основ. Так, він походить від французької «organisation» та латинського «organize» - надаю впорядкований вигляд, улаштовую; від грецької «organon» - інструмент, пристрій [1;2, с.463]. У літературі це слово тлумачиться наступним чином: дія за знач, організувати, організовуватися; об'єднання людей, суспільних груп, держав на базі спільності інтересів, мети, програми дій і таке інше [3, с.853].

У науці управління під організацією розуміється діяльність, спрямована на створення ефективної системи та структури управління. При цьому, найчастіше в зазначеній сфері наукових знань переважає поняття «організація роботи» або «організація управління». Зокрема, I.E. Марочкін, П.М. Каркач, О.Б. Червякова вважають, що організацію роботи варто розглядати у двох аспектах. Згідно з першим, - це комплекс заходів, спрямованих на раціональний розподіл праці, створення її належних умов і підтримку організаційного порядку, здорової психологічної атмосфери в колективі. До другого аспекту науковці відносять повсякденну процесуальну й непроцесуальну діяльність прокурора, пов’язану 3 поставленням підлеглим конкретних завдань, контролем за їх виконанням i оцінкою проведеної роботи. Динамічний аспект організації роботи прокуратури охоплює також суть оперативного керівництва роботою працівників прокуратури $[4$, с.5].

Отже, поняття «організація» містить у собі глибоке змістовне навантаження, внаслідок чого може тлумачитись двояко. 3 одного боку, організація - це особлива сукупність певних об'єктів, що характеризується жорсткою внутрішньою упорядкованістю, найвищим ступенем внутрішньої дисципліни елементів, які не просто співіснують між собою, але й взаємодіють. Відповідно до іншого тлумачення, організація - це упорядковуюча діяльність, метою якої $є$ приведення певної системи об'єктів до відповідного стандартизованого, заздалегідь визначеного вигляду. Таким чином, говорячи про організаційні заходи із забезпечення протидії правопорушенням у сфері господарської діяльності, ми маємо на увазі сукупність дій управлінського характеру, які направлено на упорядкування внутрішньої структури, внутрішньовладних процесів, які виникають уц поточній діяльності суб'єктів адміністративно-правової протидії досліджуваному в статті явищу. 
Розглянемо більш детально окремі організаційні заходи із забезпечення протидії правопорушенням у сфері господарської діяльності для оцінки їх з різних сторін. Так, якщо проаналізувати законодавство, то можливо виділити декілька груп адміністративно-організаційних заходів у галузі забезпечення протидії правопорушенням у сфері господарської діяльності. Першими з них можна виділити заходи структурно-управлінського значення, метою якої є формування дієвої, централізованої системи органів, які 6 проводили ефективну роботу в галузі протидії зазначеному типу правопорушень. Наприклад, КМУ спрямовує і координує роботу міністерств та інших центральних органів виконавчої влади, які забезпечують проведення державної політики у відповідних сферах суспільного і державного життя, виконання Конституції та законів України, актів Президента України, додержання прав і свобод людини та громадянина. Діяльність центральних органів виконавчої влади, керівники яких не входять до складу Кабінету Міністрів України, спрямовується і координується міністрами. Питання діяльності таких центральних органів виконавчої влади представляють відповідні міністри, до сфери спрямування і координації яких належать ці органи. КМУ затверджує граничну чисельність працівників міністерств та інших центральних органів виконавчої влади в межах коштів, передбачених у Державному бюджеті України для утримання органів виконавчої влади [5]. Так, постановами Кабінету Міністрів України затверджено положення про Державну податкову службу України та нормативно-правовий акт, який регламентує діяльність Міністерства розвитку економіки, торгівлі та сільського господарства. Крім того, у своїй поточній діяльності КМУ регулює та координує роботу цих відомств, кожне з яких виступає суб'єктом адміністративно-правової протидії правопорушенням у сфері господарської діяльності.

Необхідно також зазначити, що окреме коло повноважень КМУ відноситься до сфери вдосконалення державного управління та державної служби, зокрема у галузі роботи органів, які виступають суб'єктами правової протидії правопорушенням у сфері господарської діяльності. Так, в означеному напряму, КМУ:

здійснює заходи щодо кадрового забезпечення органів виконавчої влади;

розробляє і здійснює заходи, спрямовані на вдосконалення системи органів виконавчої влади 3 метою підвищення ефективності їх діяльності та оптимізації витрат, пов'язаних з утриманням апарату управління;

затверджує граничну чисельність працівників органів виконавчої влади;

визначає відповідно до законодавства умови оплати праці працівників бюджетних установ та підприємств державного сектору економіки, а також грошового забезпечення військовослужбовців (осіб рядового і начальницького складу), поліцейських;

організовує проведення єдиної державної політики у сфері державної служби;

утворює, реорганізовує і ліквідує міністерства та інші центральні органи виконавчої влади відповідно до закону в межах коштів, передбачених у Державному бюджеті України на утримання органів виконавчої влади, затверджує положення про зазначені органи тощо [5].

У цьому ж аспекті варто відмітити Антимонопольний комітет України, який для реалізації покладених на нього завдань має право утворювати в областях, містах Києві та Севастополі територіальні відділення Антимонопольного комітету України, повноваження яких визначаються Комітетом у межах його компетенції. У разі необхідності можуть утворюватися міжобласні територіальні відділення. Територіальне відділення Антимонопольного комітету України очолюе голова територіального відділення. Голова територіального відділення та його заступник призначаються та звільняються Головою Антимонопольного комітету України [6].

До другої групи організаційних заходів варто віднести процедури, які здійснюються з метою внутрішньої координації своєї роботи суб'єктами реалізації адміністративно-правової протидії. Так, наприклад, 


\section{Адміністративне право}

відповідно до законодавства Міністерство розвитку економіки, торгівлі та сільського господарства 3 метою організації своєї внутрішньої діяльності: забезпечує в межах повноважень, передбачених законом, здійснення заходів щодо запобігання корупції і контроль за ї реалізацією в апараті Мінекономіки, на підприємствах, в установах та організаціях, що належать до сфери його управління; здійснюе добір кадрів в апарат Мінекономіки та на керівні посади підприємств, установ і організацій, що належать до сфери його управління, організовує роботу з підготовки, перепідготовки та підвищення кваліфікації державних службовців і працівників апарату Мінекономіки; контролюе діяльність підприємств, установ та організацій, що належать до сфери його управління [7].

Аналогічні положення містяться в нормативно-правовому матеріалі, котрим регламентовано діяльність Державної податкової служби України. Так, остання, 3 метою організації своєї діяльності:

здійснює добір кадрів в апарат ДПС та на посади керівників і заступників керівників їі територіальних органів, організовує роботу з підготовки та підвищення кваліфікації працівників апарату ДПС, їі територіальних органів;

забезпечує в межах повноважень, передбачених законом, здійснення заходів щодо запобігання та виявлення корупції i контроль за дотриманням вимог антикорупційного законодавства в апараті ДПС, iii територіальних органах, на підприємствах, в установах, організаціях, що належать до сфери її управління;

організовує роботу апарату ДПС, ïi територіальних органів, підприємств, установ, організацій, що належать до сфери іiі управління;

координуе та контролюе діяльність територіальних органів ДПС та організовує їх взаємодію 3 державними органами та органами місцевого самоврядування;

надає територіальним органам ДПС методичну i практичну допомогу в організації роботи, проводить перевірку стану такої роботи;

\footnotetext{
Свропейські перспективи № 3, $2020=$

забезпечує охорону державної таємниці відповідно до вимог режиму секретності, кіберзахист, технічний та криптографічний захист інформації і здійснює контроль за його станом;

забезпечує згідно із законодавством надання державним органам інформації 3 реєстрів, банків і баз даних, ведення яких покладено законодавством на ДПС;

здійснює в межах повноважень, передбачених законом, спільно з відповідними центральними органами виконавчої влади контроль за використанням державних коштів, передбачених для реалізації проектів, виконання програм, зокрема міжнародних;

здійснює комплекс заходів для забезпечення дотримання законності та ефективності використання бюджетних коштів, досягнення результатів відповідно до встановленої мети, завдань, планів і вимог щодо діяльності ДПС, іiі територіальних органів, підприємств, установ, організацій, що належать до сфери іії управління;

організовуе планово-фінансову роботу в апараті ДПС та їі територіальних органах, здійснює контроль за використанням фінансових і матеріальних ресурсів, забезпечує організацію та вдосконалення бухгалтерського обліку в установленому законодавством порядку;

бере участь у формуванні пропозицій до державного замовлення на підготовку та підвищення кваліфікації фахівців у сфері державної податкової справи в установленому законодавством порядку;

організовуе роботу з ведення діловодства та архівного зберігання документів відповідно до встановлених правил;

забезпечує в межах своїх повноважень реалізацію державної політики щодо державної таємниці та захисту інформації, контроль за іiї збереженням у ДПС, а також мобілізаційну підготовку, мобілізацію та контроль за здійсненням таких заходів; забезпечує самопредставництво ДПС у судах через Голову ДПС, а також без окремого доручення Голови ДПС через його заступників та державних службовців самостійних структурних підрозділів апарату ДПС відповідно до положень про 
такі підрозділи, які забезпечують самопредставництво інтересів ДПС у судах без окремого доручення Голови ДПС. [8].

Третю групу організаційних заходів становлять процедури інформаційно-аналітичного характеру. Процес обробки тих чи інших відомостей, шляхом їх аналізу та визначення на основі цього пріоритетних шляхів подальшого функціонування органу є важливою частиною функціоналу суб'єктів адміністративно-правової протидії правопорушенням у сфері господарської діяльності. Робота подібного типу дозволяє не тільки внормувати діяльність відповідного органу, але й постійно визначати недоліки, які заважають ефективно виконувати передбачені законом завдання.

Так, інформаційно-аналітичні процедури притаманні процесу роботи Національної поліції України. Для реалізації своїх повноважень поліція здійснює інформаційно-аналітичну діяльність, у рамках якої: формує бази (банки) даних, що входять до єдиної інформаційної системи Міністерства внутрішніх справ України; користується базами (банками) даних Мiністерства внутрішніх справ України та інших органів державної влади; здійснює інформаційно-пошукову та інформаційноаналітичну роботу; здійснює інформаційну взаємодію 3 іншими органами державної влади України, органами правопорядку іноземних держав та міжнародними організаціями [9].

Відповідний тип організаційних заходів притаманний також у роботі інших суб'єктів адміністративно-правової протидії правопорушенням у сфері господарської діяльності, наприклад, Антимонопольного комітету України. Так, у структурі зазначеного відомства передбачено такий елемент, як апарат. Апарат Антимонопольного комітету України, його територіальних відділень здійснює роботу із забезпечення діяльності Антимонопольного комітету України та його органів, територіальних відділень Антимонопольного комітету України, в тому числі організаційну, технічну, аналітичну, інформаційно-довідкову та іншу роботу [6].

\section{Висновки}

Отже, здійснений у статті науковий аналіз дав можливість встановити, що організаційні заходи займають важливе місце у функціоналі суб'єктів протидії правопорушенням в сфері господарської діяльності. Про їх значимість та важливість досить яскраво каже той факт, що у своїй багатоманітності дані заходи об'єднуються в групи, а саме: заходи структурно-управлінські, внутрішньо-координаційні та інформаційно-аналітичні. Таким чином, організаційні заходи $є$ необхідними аспектами підтримки ефективності діяльності, а також удосконалення роботи органів влади, що в кінцевому результаті має позитивний вплив на рівень дієвості реалізованої ними протидії правопорушенням у сфері господарської діяльності.

\section{入iтература}

1. Ожегов С.И. Словарь русского языка / С.И. Ожегов // М., 1997. 788с.

2. Философский энциклопедический словарь / [гл. ред.: Л. Ф. Ильичев, П. Н. Федосеев, С. М. Ковалев, В. Г. Панов]. М. : БСЭ, 1983. $782 \mathrm{c.}$

3. Великий тлумачний словник сучасної _української мови (з дод. і допов.) / Уклад, i голов, ред. В. Т. Бусел. К.; Ірпінь: ВТФ «Перун», 2005. 1728 с.

4. Організація роботи в органах прокуратури: навч. посіб. для юрид. вузів і факультетів / [I.Є. Марочкін, П.М. Каркач, О.Б. Червякова та ін.]; за заг. ред. проф. I.C. Марочкіна, доц. О.М. Толочка. Х.: Національна юридич на академія України імені Ярослава Мудрого, 2002. 196 с.

5. Про Кабінет Міністрів України: закон від 27.02.2014 №794-VIII // Відомості Верховної Ради України. 2014. №13. ст.222.

6. Про Антимонопольний комітет України: закон від 26.11.1993 №3659-XII // Biдомості Верховної Ради України. 1993. №50. ст.472.

7. Питання Міністерства розвитку економіки, торгівлі та сільського господарства: постанова, положення від 20.08.2014 №459 // Офіційний вісник України. 2014. №77. ст.116. 
8. Про затвердження положень про Державну податкову службу України та Державну митну службу України: постанова, положення від 06.03.2019 №227 // Офіційний вісник України. 2019. №26. ст.900.

9. Про Національну поліцію: закон від 02.07.2015 №580-VIII // Відомості Верховної Ради України. 2015. №40-41. ст.379.

\section{SUMMARY}

The article analyzes the essence and concept of organizational measures to ensure the fight against crime in the sphere of economic activity in Ukraine. On the example of legislative provisions the theoretical position concerning structural-administrative, internal-coordination and information-analytical measures of maintenance of counteraction to offenses in the economic sector of the state is constructed.

It is proved that the concept of "organization" contains a deep content load, as a result of which it can be interpreted in two ways. On the one hand, an organization is a special set of certain objects, characterized by a rigid internal order, the highest degree of internal discipline of elements that not only coexist with each other, but also interact. According to another interpretation, an organization is a streamlining activity aimed at bringing a certain system of objects to a corresponding standardized, predetermined form. Thus, speaking of organizational measures to combat crime in the field of economic activity, we mean a set of managerial actions aimed at streamlining the internal structure, internal power processes that arise in the current activities of the subjects of administrative and legal counteraction studied in articles of the phenomenon.

It is established that organizational measures occupy an important place in the functionality of the subjects of counteraction to offenses in the sphere of economic activity. The fact that in their diversity these measures are grouped into groups, namely: structuralmanagerial, internal-coordination and informationanalytical measures, speaks volumes about their significance and importance. Thus, organizational measures are necessary aspects of maintaining the efficiency of activities, as well as improving the work of public authorities, which ultimately has a positive impact on the level of effectiveness of their response to economic offenses.

Key words: offenses, economic activity, organizational measures, counteraction. 